Berthet, A.; Heredia-Ortiz R. ; Vernez, D. ; Danuser, B. ; Bouchard, M.

A Detailed Urinary Excretion Time Course Study of Captan and Folpet

Biomarkers in Workers for the Estimation of Dose, Main Route-of-

Entry and Most Appropriate Sampling and Analysis Strategies

Annals of Occupational Hygiene, 56(7):815-828, 2012.

\begin{tabular}{|l|l|}
\hline Postprint version & Final draft post-refereeing \\
\hline Journal website & $\underline{\text { http://annhyg.oxfordjournals.org/content/by/year }}$ \\
\hline Pubmed link & $\underline{\text { http://www.ncbi.nlm.nih.gov/pubmed/22425654 }}$ \\
\hline DOI & $\underline{10.1093 / \text { annhyg/mes011 }}$ \\
\hline
\end{tabular}




\title{
A Detailed Urinary Excretion Time Course Study of Captan and Folpet Biomarkers in Workers for the Estimation of Dose, Main Route-of-Entry and Most Appropriate Sampling and Analysis Strategies
}

\begin{abstract}
AURÉLIE BERTHET ${ }^{1,2}$, ROBERTO HEREDIA-ORTIZ ${ }^{1}$, DAVID VERNEZ ${ }^{2}$, BRIGITTA DANUSER ${ }^{2}$ and MICHÈLE BOUCHARD ${ }^{1 *}$

${ }^{1}$ Department of Environmental and Occupational Health, School of Public Health, Université de Montréal, P.O. Box 6128, Main Station, Montreal, Quebec, Canada, H3C 3J7; ${ }^{2}$ Institute for Work and Health, Bugnon 21, 1011 Lausanne, Switzerland
\end{abstract}

*Author to whom correspondence should be addressed. Tel: +1-514-343-6111 ext 1640; fax:+1-514-343-2200; e-mail: michele.bouchard@umontreal.ca

Keywords: captan; folpet; field workers; exposure assessment; biomonitoring; dose reconstruction spraying activities; re-entry activities 


\begin{abstract}
Captan and folpet are two fungicides largely used in agriculture, but biomonitoring data are mostly limited to spot urine/ individual void? measurements of concentrations of captan metabolites in workers, which complicate interpretation of results in terms of internal dose estimation, daily variations according to tasks performed and most plausible routes of exposure. This study aimed at performing repeated biological measurements of exposure to captan and folpet in field workers i) to better assess internal dose along with main routes-of-entry according to tasks and ii) to establish most appropriate sampling and analysis strategies. The urinary excretion time courses of specific and non-specific biomarkers of exposure to captan and folpet were established in tree farmers $(n=2)$ and grapegrowers $(n=3)$ over a typical work week (7 consecutive days), including spraying and harvest activities. The impact of the expression of urinary measurements (excretion rate values adjusted or not for creatinine or cumulative amounts over given time periods $(8,12,24 \mathrm{~h}))$ was evaluated. Absorbed doses and main routes-of-entry were then estimated from the 24-h cumulative urinary amounts, through the use of a kinetic model. The time courses showed that exposure levels were higher during spraying than harvest activities. Model simulations also suggest a limited absorption in the studied workers and an exposure mostly through the dermal route. It further pointed out the advantage of expressing biomarker values in terms of body-weight adjusted amounts in repeated 24-h urine collections as compared to concentrations or excretion rates in spot samples, without the necessity for creatinine corrections.
\end{abstract}




\section{INTRODUCTION}

Captan ( $N$-(trichloromethylthio)-4-cyclohexene-1,2-dicarboximide) and folpet $(N$ [trichloromethylthio]phthalimide) are two common dicarboximide fungicides used in various crops. Captan was patented by Kittleson (1952) and first introduced in 1951, while folpet was first registered as a pesticide in 1948. Both compounds have thus been used by workers for almost 60 years, but their health effects are still controversial and mostly documented from animal toxicity studies.

The U.S. Environmental Protection Agency (1975; 1999) initially classified both fungicides as probable human carcinogens (B2) based on an increased incidence of duodenum tumors in mice chronically exposed to high doses by gavage. However, in 2004, the Agency revised the classification of captan and changed it to "not likely" considering that the doses administered to the mice were much higher than those encountered in occupational settings, and induced proliferation of nascent tumors through cytotoxicity and cell hyperplasia (Gordon, 2007; US EPA, 2004). Similarly, Cohen et al. (2010) demonstrated in their review that folpet is not likely to be a human carcinogen for the same reasons as captan, and Greenburg et al. (2008) found no evidence of an increase in the incidence of cancer among applicators exposed to captan over a 9-year period. Captan has also been classified as a Group 3 carcinogen (or limited evidence of carcinogenicity in experimental animals) by the International Agency for Research on Cancer (IARC, 1987) and in Group A3 (or confirmed animal carcinogen with unknown 
relevance to humans) by the American Conference of Governmental Industrial Hygienists (ACGIH, 2010). Folpet is not listed in the index of the latter two organizations.

Even though no systemic toxicity of captan and folpet was reported in humans, both fungicides are considered as sensitizers and strong irritants of the eyes, skin and respiratory airways (ACGIH, 1991; Costa, 2008; Edwards et al., 1991; Gordon, 2010; Hayes, 1982; NIOSH, 2007; Tomlin, 1997; Trochimowicz et al., 1991; US EPA, 1999; US EPA, 2004). A few studies reported skin problems (i.e. allergic reactions, dermatitis) in workers exposed to captan or folpet (Burroughs and Hora, 1982; Guo et al., 1996; Lisi et al., 1987). Burroughs and Hora (1982) also mentioned that $48.4 \%$ of workers employed in a fungicide production plant stated having eye problems (i.e. burning, itching and tearing of eyes) and 58.1\% declared suffering from respiratory problems (i.e. dry throat, sore throat, coughing, wheezing, shortness of breath, difficulty breathing) ( $n=$ 66). As a result, occupational guidelines were proposed for captan, namely a TLV ${ }^{\circledR}$-TWA of $5 \mathrm{mg} / \mathrm{m}^{3}$ (ACGIH, 2010) or a Recommended Exposure Limit (REL ${ }^{\circledR}$ ) of $5 \mathrm{mg} / \mathrm{m}^{3}$ (NIOSH, 2007), but none are available to date for folpet, except the recommendation by the US EPA (1999) to wear gloves when handling the product. Therefore, risks related to occupational exposure to captan and especially folpet are not well defined.

Worker exposure and absorption may also be affected by multiple factors and conditions. For instance, in addition to frequent reported factors such as the dose, exposure duration, vehicle, skin conditions and its composition, or physicochemical characteristics of compounds, others factors such as the type of crop, meteorological conditions, the delay 
of re-entry, or work habits and practices may also be important determinants of exposure and absorption (Geer et al., 2004; Hughes et al., 2006; Stewart et al., 2001; Tielemans et al., 1999; Winterlin et al., 1986; Zweig et al., 1985).

To identify factors or activities most likely to increase worker exposure to captan, some authors have performed environmental measurements using personal dosimeters or skin pads, while assessing the impact of wearing masks or hand washing (Burroughs and Hora, 1982; Mcjilton et al., 1983; Oudbier et al., 1974; Ritcey et al., 1987; Stevens and Davis, 1981; Tielemans et al., 1999; Zweig et al., 1985). However, external exposure measurements are known to present limitations and to lead to overestimations of true absorbed doses. The best means of accurately assessing worker exposure to such type of compound is recognized to be through biological monitoring, since it allows estimating actual rather than potential absorption by workers and integrating exposure by all routes (de Cock et al., 1995; He, 1993; Woollen, 1993).

Some field studies have attempted to associate environmental measurements with biomonitoring data to assess captan exposure (de Cock et al., 1995; Hansen et al., 1978; Hines et al., 2008; Krieger and Dinoff, 2000; Lavy et al., 1993; Maddy et al., 1989; Winterlin et al., 1984; Winterlin et al., 1986), but poor correlations were obtained. These studies, as well as those of van Welie et al. (1991) and of Verberk et al. (1990) which used only biomonitoring, assessed worker exposure for a maximum three consecutive days, with incomplete collections; typical tasks involving potential exposure to captan (e.g. spraying and harvest activities) were also assessed in workers. However, according 
to some authors (Ross et al., 2001; Thongsinthusak et al., 1999; Woollen, 1993), to accurately estimate absorption, especially though the dermal route, the optimal sampling protocol would be to collect 24-h voids for seven days, in a worker performing different tasks during a workweek and thus subjected to various exposure scenarios.

By comparison with captan, there is a paucity of data on occupational exposure to folpet, although it is also widely used in agriculture. The only available data comes from a health hazard report conducted by the NIOSH (Burroughs and Hora, 1982) to evaluate captan and folpet exposure in about 60 employees working in a fungicide production plant through environmental and medical evaluation.

There is thus a need to better assess occupational exposure to these two fungicides and this can effectively be achieved through biomonitoring. Nonetheless, such approach requires a minimum knowledge of the toxicokinetics of the compound under study, hence of major metabolites, together with a sensitive analytical method for their quantification in accessible biological matrices (Wester and Maibach, 1983;Woollen, 1993). For the biomonitoring of worker exposure to captan, tetrahydrophthalimide (THPI) was quantified in the published studies as a urinary metabolite of captan due to its stability. Its interest as a biomarker of exposure was confirmed by our previous kinetic studies in volunteers orally and dermally exposed to captan in controlled conditions (Berthet et al., $2011 \mathrm{a}, \mathrm{b})$. According to the time course data of Berthet et al. (2011a,b), phthalimide (PI) and total ring-metabolites of folpet (expressed as phthalic acid equivalents $\left(\mathrm{PA}_{\mathrm{eq}}\right)$ ) also proved to be two potentially useful biomarkers of folpet exposure. 
This study thus aimed at i) better assessing occupational exposure to captan and folpet through repeated biological measurements in field workers $(n=5)$ following spraying and harvest activities (internal dose and main route-of-exposure) and ii) establishing most appropriate sampling and analysis strategies. 


\section{MATERIALS AND METHODS}

Study design

The detailed time profiles of key biomarkers of exposure to captan and folpet were characterized in the urine of agricultural workers subjected to different exposure scenarios, preparing/mixing/loading/spraying activities and harvest activities following the 48-h required delay of re-entry. Captan and folpet ring-metabolites were quantified in pre-seasonal urines and, for each exposure scenario, in all urines voided over seven consecutive days. From these data, the dose absorbed by workers and main route-of-entry were estimated using toxicokinetic models previously developed by our team, which allow to reconstruct absorbed doses of captan and folpet from biomarker data considering different exposure scenarios (Heredia et al., 2011a,b).

The experimental protocol and consent forms were approved by the Permanent Ethics Committee for Clinical Research of the Faculty of Biology and Medicine of the University of Lausanne (protocole 134/07) and the Research Ethics Committee of the Faculty of Medicine of the University of Montreal (CERFM (06)\#227). All the participants gave their written consent, and were informed of the risks of participating and their right to withdraw from the study at anytime. 


\section{Studied workers}

Participants were recruited on a voluntary basis among tree farmers and grapegrowers living within 100-km from Lausanne (Switzerland). Approximately twelve workers were contacted, but only five persons accepted to participate, namely two tree farmers (exposed to captan) and three grapegrowers (exposed to folpet), due to the restrictive protocol. All participants were male workers aged between 35 and 55 years old, weighing 74 to $115 \mathrm{~kg}$ and measuring 178 to $192 \mathrm{~cm}$. They were healthy and non-smokers, and underwent a medical examination by an occupational physician prior to enrollment.

\section{Urine sample collection}

Urine sample collections were conducted over seven consecutive days (or $168 \mathrm{~h}$ ) following two different types of exposure, namely spraying activities (including preparing, mixing and loading tasks) and harvest activities following the required re-entry delay (i.e. pruning, thinning), except for one grapegrower performing harvest activities who collected all his urine voided over a 72-h period. During the collection period, several spraying techniques were used by the studied workers (i.e. tractors with closed or half-opened cabins, small airblast sprayers and back air-sprayers) and sampling was conducted during the season period presumed to be associated with worst exposure scenarios. 
More specifically, to determine urinary baseline levels of the studied metabolites, a preseasonal complete first-morning void was collected for each worker; during this period, they were not occupationally exposed to captan or folpet. At the beginning of the fungicide treatment period, workers were then asked to provide all urine voided during the course of a typical workweek involving a spraying episode of captan or folpet (in general, a 168-h collection period with spraying the first sampling day). Each void was collected in separate polypropylene Nalgene ${ }^{\circledR}$ bottles of 11 ; workers were asked to indicate the date and time of urine collection on the pre-coded bottle labels.

During the high season of thinning activities and pruning of vineyards or orchards, the same workers were again asked to provide a second round of urine collection. During this period, the vegetation was dense and abundant, and workers were easily in contact with treated leaves. All urine voided during the course of a typical workweek involving harvest activities were thus collected following the required delay of re-entry (in general, a 168-h collection period with harvest activities on several days). At least two weeks separated the two exposure scenarios.

Once collected, urine samples were kept in the refrigerator and daily picked up by our team. Total urine volume per void was then measured upon arrival at the laboratory. To allow repeated analysis while avoiding possible degradation due to freezing and thawing of samples, each urine collection was then aliquoted in 4 labelled tubes of $15 \mathrm{ml}$ and one bottle of $120 \mathrm{ml}$ prior to storage at $-20^{\circ} \mathrm{C}$ until analysis. 
In addition, during each urinary collection period, workers were invited to complete a timesheet with the actual time of each voiding and to indicate whether or not there were any urine losses. They were also asked to fill a questionnaire to document personal factors (weight, height), information related to spraying and harvest activities (i.e. commercial product name, application days, techniques, tasks), work habits (i.e. safety equipments, decontamination tasks, hand washing), treatments (i.e. other captan/folpet treatments or other pesticides sprayed during the study period), life habits (i.e. physical activities, smoking), medication intake (including ibuprofen) and possible symptoms during workdays. Distinct questionnaires were elaborated for the two exposure scenarios and adapted to the tasks performed.

\section{Sample analysis}

THPI and PI. THPI and PI were quantified in urine according to the method of Berthet et al. (2011c). In short, THPI and PI were isolated by solid phase extraction (SPE), eluted in dichloromethane and analyzed by liquid chromatography - atmospheric pressure chemical ionization-tandem mass spectrometry (LC/APCI-MS/MS), in negative ion mode. The fragments analyzed were $\mathrm{m} / z$ 149.4/95.6 for THPI, $m / z$ 156.1/95.6 for the internal standard THPI-d, and $m / z 145.8$ for PI (no fragmentation). The analytical limit of detection in urine was $3.8 \mathrm{nmol}^{-1}$ and $7.7 \mathrm{nmol}^{-1}$ for THPI and PI, respectively. The quantification of THPI or PI was obtained from standard calibration curves prepared in urine or plasma adjusted by the THPI-d internal standard peak area. 
Phthalic acid equivalents. Total ring-metabolites of folpet, expressed as $\mathrm{PA}_{\mathrm{eq}}$, were measured according to the method of Berthet et al. (2011d). Briefly, urine samples were subjected to an acid hydrolysis prior to liquid-liquid extraction with ethyl acetate and derivatization with N,O-bis(trimethylsilyl)trifluoroacetamide (BSTFA). Analysis was then performed by gas chromatography - mass spectrometry (GC-MS). The ions monitored were trimethylsilyl phthalic acid with $\mathrm{m} / \mathrm{z} 295$ and the internal standard TMS methylhippuric acid with $\mathrm{m} / \mathrm{z}$ 220. The quantification was obtained from standard calibration curves of phthalic acid prepared in urine and adjusted by the methylhippuric acid internal standard peak height. The analytical limit of detection was $60.2 \mathrm{nmol} \mathrm{l}^{-1}$ urine.

\section{Creatinine}

Creatinine was measured in urine by an alkaline picric acid method with deproteinization, namely by the Jaffé method with deproteinization (enzymatic colorimetric test PAP from Boehringer Mannheim, Germany).

To adjust THPI, PI and $\mathrm{PA}_{\mathrm{eq}}$ urinary excretion rates by creatinine contents, the following equation, described by Viau et al. (2004), was used:

$$
\left[\left(\frac{\Delta \text { metabolite }}{\Delta t}\right)\right]_{\mathrm{Adj}}=\left[\left(\frac{\Delta \text { metabolite }}{\Delta t}\right)\right]_{i} \times \frac{\left[\frac{\Delta \text { Creatinine }}{\Delta t}\right]_{\text {mean }}}{\left[\frac{\Delta \text { Creatinine }}{\Delta t}\right]_{i}}
$$


where $\left[\left(\frac{\Delta \text { metabolite }}{\Delta t}\right)\right]_{\text {Adj }}$ is the adjusted excretion rate of the studied metabolite, $\left[\left(\frac{\Delta \text { metabolite }}{\Delta t}\right)\right]_{i}$ is the excretion rate observed over a determined time interval $i$ $\left[\frac{\Delta \text { Creatinine }}{\Delta t}\right]_{\text {mean }}$ is the average creatinine excretion rate for the total study period, and $\left[\frac{\Delta \text { Creatinine }}{\Delta t}\right]_{i}$ is the average creatinine excretion rate over a determined time interval $i$.

\section{Toxicokinetic modeling}

Multi-compartment toxicokinetic models were developed to describe the time courses of captan and folpet key biomarkers in accessible biological matrices following multi-routes of exposure (Heredia et al. 2011a,b). A specific model was built to describe the kinetics of THPI metabolite of captan. On the other hand, the kinetics of PI and PA eq metabolites of folpet were modeled separately. These models were used in the current study to reconstruct the absorbed doses of these fungicides in workers from serial urinary biomarker measurements and to obtain an indication of the predominant route of exposure for these workers.

Briefly, in the models, the body was represented by compartments. The rates of change in the amounts of compounds or its metabolites in the different compartments were represented by a set of linear first-order ordinary differential equations. Kinetics of fungicides and their experimentally relevant metabolites were modeled for three different exposure routes: oral, dermal and inhalation. To describe oral exposure, the considered compartments were the parent compound and its almost instantaneously generated 
metabolites in the gastrointestinal tract, the body burden of metabolites in blood and in tissues in dynamical equilibrium with blood, both monitored and non-monitored, and the different excretion compartments representing cumulative amounts of monitored metabolites in urine and feces. To simulate dermal exposure, the epidermis and dermis were represented by distinct compartments (except for the kinetics of $\mathrm{PA}_{\text {eq }}$ given the absence of measured blood time course of $\mathrm{PA}_{\mathrm{eq}}$, which simplifies model representation). Lastly, inhalation exposure was modeled with direct inputs to the blood compartment due to the rapid absorption of both fungicides through the respiratory tract (Canal-Raffin et al. 2006, 2007). All amounts in models were initially expressed on a molar basis (see supplementary information for model representation and parameter values). 


\section{RESULTS}

Worker exposure

Table 1 summarizes the characteristics, exposure conditions and activities of the workers under study. In the case of workers exposed to captan, field spraying was conducted using tractors with a cabin; they did not wear masks or coveralls during spraying or harvest activities, and only one wore gloves during preparation, mixing, loading and cleaning tasks, but not during harvest activities. In the case of workers exposed to folpet, they tended to protect themselves better since all wore masks during preparation and spraying activities as well as gloves and pants during harvest activities. This increased protection was probably due to the fact they used airblast sprayers or back air-sprayers to apply folpet and were thus more likely to be in contact with the applied fungicide. Two workers reported eye irritations following folpet spraying and one of these two workers also reported eye irritation following harvest activities, while no symptoms were mentioned by workers exposed to captan.

To assess the importance of exposure due to spraying and harvest activities considering the previously mentioned exposure conditions, THPI was measured in urine as a biomarker of exposure to captan while PI and $\mathrm{PA}_{\mathrm{eq}}$ were quantified to assess folpet exposure. Figure 1 depicts the urinary time profiles of THPI in the two studied workers over a 7-day period following captan spraying or harvesting in a captan-treated area; Figure 2 presents corresponding time profiles for PI and $\mathrm{PA}_{\mathrm{eq}}$ biomarkers of exposure to 
folpet in the three studied workers. Exposure to captan was found to be higher during spraying than harvest activities. This is particularly apparent for worker 2 since he was barely exposed during harvest activities, with values close to pre-seasonal levels. Worker 2 appeared more exposed than worker 1 over the spraying period, but he did not wear gloves during work and he manipulated larger amounts of captan given that he had to treat a broader area. Similarly, workers seemed more exposed to folpet during spraying than harvest activities. This is especially apparent from the time profiles of PI and $\mathrm{PA}_{\mathrm{eq}}$ in worker 2. However, differences in excretion values between both activities were less noticeable than for captan. As presented in Table 1, workers exposed to folpet were better protected during spraying activities contrary to workers exposed to captan.

From Figure 2, the urinary time courses of PI and $\mathrm{PA}_{\mathrm{eq}}$ in workers following spraying and harvesting can also be compared. As expected, similar profiles were obtained for both biomarkers, except for worker 1 during spraying period. This allowed pointing out a substantial baseline level of phthalic acid in workers due to an exposure other than folpet.

\section{Creatinine adjustments and timed collections}

Figures 3 and 4 show the impact of creatinine adjustment on the urinary excretion time course of THPI and PI along with profile variations when expressing urinary results in terms of spot or pooled measurements over 8,12 or 24 -h periods. Results show that creatinine adjustment had little effect on the time courses of biomarkers in spot or pooled samples, as non-adjusted and creatinine-adjusted rate profiles were found to 
quantitatively evolve in a similar manner. This was even more evident with pooled urines, especially 24 -h urine collections. Figures 3 and 4 also show that excretion rate profiles were less variable when urines were pooled over the longest period of time, hence $24 \mathrm{~h}$. In contrast with 24-h collections, it was also less obvious to infer on the main route-of-exposure from individual voids due to the important variations between some data points.

\section{Exposure route simulations}

Figure 5 shows an example of model simulation of the time courses of THPI and PI metabolites in workers for both spraying and harvest scenarios, considering the various possible absorption routes (inhalation, dermal or oral). Simulations of a dermal exposure scenario for both captan and folpet, during spraying period as well as harvest activities, provided the closest description of the observed time courses as compared to oral and inhalation scenarios. However, contrary to workers exposed to captan, it was less obvious from observed time courses of folpet metabolites that dermal absorption was in all cases the predominant exposure route of folpet exposure for workers. 


\section{DISCUSSION}

Results of the present study show notable variations in captan and folpet biomarker levels according to field tasks, such as spraying or harvest activities. Through biomonitoring, it was thus evidenced that workers were more exposed during application than harvest activities. Model simulations of urinary time course data considering various exposure route scenarios further indicated that captan was mainly absorbed through the skin following both spraying and harvesting. For folpet, main exposure route is less obvious but model simulations of a dermal scenario provided the closest approximation of the observed data (Figure 5). This does not exclude a certain concomittant inhalation exposure in the studied workers. In addition, collections of complete voids over seven consecutive days allowed confirming that measurements of biomarkers in 24-h collections without creatinine normalization provided the most reliable assessment of worker exposure to captan and folpet.

Comparison of exposure levels between spraying and harvest activities

According to biomonitoring results in the studied workers (Figures 1 and 2), exposure to captan and folpet were more important during spraying period than harvest activities. This is probably due mostly to mixing and loading prior to spaying as suggested by de Cock et al. (1998a). However, exposure during spraying was of shorter duration and less frequent, and workers were more protected (Table 1). The same observations were 
reported in studies assessing captan exposure through spot measurements (de Cock et al., 1998a; Geer et al., 2004; Krieger, 1995; Tielemans et al., 1999; Winterlin et al., 1986).

Thus, harvest activities following a re-entry in treated fields resulted in limited dermal absorption according to biomonitoring results in the studied workers (Figures 1 and 2), even though half-life of captan on leaf surfaces was estimated to be between 2.5 to 24 days (Alary et al., 1995; Cabras et al., 1997, 2000; de Cock et al., 1998a; el-Zemaity, 1988; Frank et al., 1983; Phalen and Que Hee, 2003; Stamper et al., 1987; Tielemans et al., 1999; US EPA, 2004; Winterlin et al., 1984). For folpet, however, results of the current study do not exclude the possibility that workers could be also exposed by oral or inhalation routes.

Although workers of the current study were more exposed during spraying than harvesting, urinary excretion values of THPI were in general lower than those reported in the literature and summarized in Table 2. For applicators exposed to captan, our mean 24$\mathrm{h}$ excretion values following the beginning of treatment period were equivalent to those obtained by Hines et al. (2008), but lower than most of the other available studies. Likewise, our workers exposed to captan during harvesting exhibited lower THPI concentrations than those of other published studies (Krieger and Dinoff, 2000; Winterlin et al., 1984; Winterlin et al., 1986). In the other studies, larger amounts of captan were however applied and a wider treatment area was covered compared to the current study. 
In addition, urinary THPI concentrations in workers exposed to captan were lower than maximum values previously observed in a controlled kinetic time course study in volunteers dermally applied $10 \mathrm{mg} \mathrm{kg}^{-1}$ of captan on $80 \mathrm{~cm}^{2}$ of the forearm during $24 \mathrm{~h}$ (Berthet et al., 2011b) (maximum concentration obtained for both workers of $44.9 \mathrm{nmol} \mathrm{l}^{-}$ ${ }^{1}$ compared to average maximum concentration for volunteers of $180 \mathrm{nmol} \mathrm{l}^{-1}$ ). On the other hand, urinary PI concentrations in two of the three studied folpet workers (workers 2 and 3) reached values similar to those observed in a kinetic time course study in volunteers dermally exposed to folpet (i.e. maximum of $18.3 \mathrm{nmol}^{-1}$ in workers compared to $17.7 \mathrm{nmol} \mathrm{l}^{-1}$ in volunteers), while maximum values in the third worker (worker 1) were rather higher (i.e. maximum of $26.9 \mathrm{nmol}^{-1}$ ).

As for the major route of exposure, current results (see model simulations in Figure 5) are in line with those previously reported and showing that dermal absorption is the primary route-of-entry for both mixers/loaders/applicators and re-entry workers in contact with pesticides (Geer et al., 2004; Gunther et al., 1977; Ritcey et al., 1987; Ross et al., 2001; Thongsinthusak et al., 1999). In particular, de Cock et al. (1995) and Hansen et al. (1978) found that respiratory exposure route to captan was minor compared to dermal absorption. 
Parameters influencing exposure assessment through biomonitoring

Biomonitoring in field workers allows estimating doses truly absorbed in workers whatever the exposure scenario (Woollen, 1993). However, depending on tasks and activities, workers are not exposed constantly or equally during a workday or a week. When feasible, it is thus preferable to obtain complete daily collections over several days to assess most accurately worker exposure, as suggested by some authors (Ross et al., 2001; Thongsinthusak et al., 1999; Woollen, 1993), instead of spot urine samples. This was also particularly evident from our results, showing that an overestimation or underestimation of exposure may be induced with punctual urines, as illustrated in Figures 3 and 4, since there are significant void-to-void variations in metabolite concentrations and urinary volumes (Spencer et al., 1995; Woollen, 1993). With combined 8-h urine collections, time profiles were better defined for the studied metabolites than with spot samples; however, it was the daily (24-h) variations in biomarker levels which allowed to reproduce most closely the time course in workers using the toxicokinetic models previously developed (Heredia et al., 2011a, b).

Creatinine normalization of metabolite excretion rates, as proposed by Viau et al. (2004), also appeared unnecessary in this study since adjusted values were close to non-adjusted values, especially in 24-h urine collections (Figures 3 and 4). Consequently, when feasible, using complete 24 -h voids over a week, including days off, appears to be the most reliable procedure to estimate worker exposure to captan and particularly folpet, given the paucity of available biomonitoring data. 
Nonetheless, complete 24-h urine collections may be burdensome for exposed workers and hardly feasible in routine biological monitoring. Based on current results and those of a previous study in volunteers dermally exposed to captan and folpet (Berthet et al., 2011b), one alternative is to collect first morning void, end-of-shift sample and last evening void during three consecutive days. Spot samples collected on several days are still needed to properly assess exposure as peak levels of THPI and PI in blood were reached only $24 \mathrm{~h}$ and $10 \mathrm{~h}$ after a dermal exposure to captan and folpet in volunteers, respectively, with ensuing mean elimination half-lives $\left(\mathrm{t}^{1} \frac{1}{2}\right)$ of 24.7 and $29.7 \mathrm{~h}$, respectively (Berthet et al., 2011b). However, to obtain a workable estimation of exposure in one spot sample, the first morning void after the last exposure may be a sampling strategy in considering the large variability between individuals and the total daily exposure will not be representative.

In summary, the present biomonitoring study used detailed repeated-measurements along with kinetic modeling tools to better assess worker exposure to captan and folpet and main route-of-entry. Despite the limited number of participants, sufficient data were obtained to confirm results reported in the literature for captan and to provide new data on folpet exposure. However, more investigations are needed to further document exposure to folpet in workers and confirm main absorption route. 


\section{FUNDING}

This study was funded by the Agence Nationale de Sécurité Sanitaire de l'alimentation, de l'environnement et du Travail (ANSES). Aurélie Berthet also received a scholarship from the Institut de recherche Robert-Sauvé en santé et sécurité du travail du Québec (IRSST). 
Acknowledgements- Authors wish to thank the five workers to their participation and their attention to respect the protocol as well as Dr. Michèle Berode, Gregory Plateel and the technicians P. Stefan, M. Nobel, C. Kohler and P. Storti (Institute for Work and Health) for their help in analytical analysis. We also thank Dr. Khanh Huynh (Institute for Work and Health) for his help with the LC/MS/APCI system. 


\section{REFERENCES}

Alary J, Bescos D, Monge MC, Debrauwer L, Bories GF. (1995) Laboratory simulation of captan residues degradation during apple processing. Food Chemistry; 54 205-211.

American Conference of Governmental Industrial Hygienists. (1991). Documentation of the threshold limit values and biological exposure indices, $6^{\text {th }}$ edition. Volumes I, II, III. Cincinnati, Ohio. American Conference of Governmental Industrial Hygienists.

American Conference of Governmental Industrial Hygienists. (2010). TLVs ${ }^{\circledR}$ and BEIs ${ }^{\circledR}$. Based on Documentation of the Threshold Limit Values for chemical substances and physical agents and Biological Exposure Indices, 7th edition. Cincinnati, Ohio. American Conference of Governmental Industrial Hygienists.

Berthet A, Bouchard M, Danuser B. (2011a) Toxicokinetics of captan and folpet biomarkers in orally exposed volunteers. J Appl Toxicol. DOI 10.1002/jat.1653.

Berthet A, Bouchard M, Vernez D. (2011b) Toxicokinetics of captan and folpet biomarkers in dermally exposed volunteers. J Appl Toxicol. DOI 10.1002/jat.1659.

Berthet A, Bouchard M, Schüpfer P, Vernez D, Danuser B, Huynh CK. (2011c) A liquid chromatography - tandem mass spectrometry (LC/APCI-MS/MS) method for the quantification of captan and folpet phthalimide metabolites in human plasma and urine. Anal Bioanal Chem; 399(6) 2243-2255. 
Berthet A, Berode M, Bouchard M. (2011d) Gas-chromatography mass-spectrometry determination of phtalic acid in human urineas a biomarker of folpet exposure. Anal Bioanal Chem; 400(2) 493-502.

Burroughs, G. E. and Hora, J. (1982). HETA-80-147-1076. Health Hazard Evaluation Calhio Chemical Company, Perry, Ohio. Cincinnati, Ohio. National Institute for Occupational Safety and Health.

Cabras P, Angioni A, Caboni P, Garau VL, Melis M, Pirisi FM, Cabitza F. (2000) Distribution of folpet on the grape surface after treatment. J Agric Food Chem; 48 915916.

Cabras P, Angioni A, Garau VL, Melis M, Pirisi FM, Farris GA, Sotgiu C, Minelli EV. (1997) Persistence and metabolism of folpet in grapes and wine. J Agric Food Chem; 45 476-479.

Canal-Raffin M, L'azou B, Martinez B, Sellier E, Fawaz F, Ohayon C, Baldi I, Cambar J, Molimard M, Moore N, Brochard P. (2006) Impact of Folpet on Respiratory System: In Vitro Studies. Epidemiology; 17(6) S90.

Canal-Raffin M, L'azou B, Martinez B, Sellier E, Fawaz F, Robinson P, Ohayon-Courtes C, Baldi I, Cambar J, Molimard M, Moore N, Brochard P. (2007) Physicochemical characteristics and bronchial epithelial cell cytotoxicity of Folpan 80 WG(R) and Myco 500(R), two commercial forms of folpet. Particle Fibre Toxicol; 4(8). 
Cohen SM, Gordon EB, Singh P, Arce GT, Nyska A. (2010) Carcinogenic mode of action of folpet in mice and evaluation of its relevance to humans. Critical Rev Toxicol; $40531-545$.

Costa LG. (2008) Toxic effects of pesticides: the basic science of poisons. In Casarett LJ, Doull J, Klaassen CD, editors. Casarett and Doull's Toxicology: the Basic Science of Poisons. McGraw-Hill: New York. p. 883-930. ISBN 9780071470513.

de Cock J, Heederik D, Hoek F, Boleij J, Kromhout H. (1995) Urinary excretion of tetrahydrophtalimide in fruit growers with dermal exposure to captan. Am J Ind Med; 28 245-256.

de Cock J, Heederik D, Kromhout H, Boleij JSM, Hoek F, Wegh H, Ny ET. (1998a) Exposure to captan in fruit growing. Am Ind Hyg Assoc J; 59 158-165.

de Cock J, Heederik D, Kromhout H, Boleij JSM, Hoek F, Wegh H, Ny ET. (1998b) Determinants of exposure to captan in fruit growing. Am Ind Hyg Assoc J; 59 166-172.

Edwards R, Ferry DG, Templ WA. (1991) Fungicides and related compounds. In Hayes WJ, Laws ER, editors. Handbook of Pesticide Toxicology. Academic Press: San Diego, CA. p. 1409-1470. ISBN 9780123341600.

el-Zemaity MS. (1988) Residues of captan and folpet on greenhouse tomatoes with emphasis on the effect of storing, washing, and cooking on their removal. Bull Environ Contam Toxicol; 40 74-79. 
Frank R, Braun HE, Stanek J. (1983) Removal of Captan from Treated Apples. Arch Environ Contam Toxicol; 12 265-269.

Geer LA, Cardello N, Dellarco MJ, Leighton TJ, Zendzian RP, Roberts JD, Buckley TJ. (2004) Comparative analysis of passive dosimetry and biomonitoring for assessing chlorpyrifos exposure in pesticide workers. Ann Occup Hyg; 48 683-695.

Gordon E. (2007) Captan: transition from 'B2' to 'not likely'. How pesticide registrants affected the EPA Cancer Classification Update. J Appl Toxicol; 27 519-526.

Gordon EB. (2010) Captan and folpet. In Krieger RI, editor. Handbook of pesticide toxicology. Elsevier: New York. p. 1915-1949. ISBN 9780123743671.

Greenburg DL, Rusiecki J, Koutros S, Dosemeci M, Patel R, Hines CJ, Hoppin JA, Alavanja MC. (2008) Cancer incidence among pesticide applicators exposed to captan in the Agricultural Health Study. Cancer Causes Control; 19 1401-1407.

Gunther FA, Iwata Y, Carman GE, Smith CA. (1977) The citrus reentry problem: research on its causes and effects, and approaches to its minimization. Residue Rev; 67 1132.

Guo YLL, Wang BJ, Lee CC, Wang JD. (1996) Prevalence of dermatoses and skin sensitisation associated with use of pesticides in fruit farmers of southern Taiwan. Occup Environ Med; 53 427-431. 
Hansen JD, Schneider BA, Olive BM, Bates JJ. (1978) Personnel safety and foliage residue in an orchard spray program using azinphosmethyl and captan. Arch Environ Contam Toxicol; 7 63-71.

Hayes WJ (1982) Fungicides and related compounds. In Hayes WJ, editor. Pesticides studied in man. Williams and Wilkins: Baltimore. p. 578-622. ISBN 9780683038965.

He F. (1993) Biological monitoring of occupational pesticides exposure. Int Arch Occup Environ Health; 65 S69-S76.

Heredia-Ortiz R, Bouchard M (2011a) Toxicokinetic modeling of captan fungicide and its tetrahydrophthalimide biomarker of exposure in humans. Toxicol Lett, doi:10.1016/j.toxlet.2011.09.023.

Heredia-Ortiz R, Berthet A, Bouchard M. (2011b) Toxicokinetic modeling of folpet fungicide and its ring-biomarkers of exposure in humans. J Appl Toxicol. In print..

Hines CJ, Deddens JA, Jaycox LB, Andrews RN, Striley CAF, Alavanja MCR. (2008) Captan exposure and evaluation of a pesticide exposure algorithm among orchard pesticide applicators in the agricultural health study. Ann Occup Hyg; 52 153-166.

Hughes EA, Zalts A, Ojeda JJ, Flores AP, Glass RC, Montserrat JM. (2006) Analytical method for assessing potential dermal exposure to captan, using whole body dosimetry, in small vegetable production units in Argentina. Pest Manag Sci; 62 811-818. 
International Agency for Research on Cancer. (1987). Captan. Overall evaluations of carcinogenicity: An updating of IARC Monographs. Volumes 1 to 42, [Supplement 7]. Lyon, France. World Health Organization.

Kittleson AR. (1952) A New Class of Organic Fungicides. Science; 115 84-86.

Krieger RI. (1995) Pesticide exposure assessment. Toxicol Lett; 82-83 65-72.

Krieger RI, Dinoff TM. (2000) Captan fungicide exposures of strawberry harvesters using THPI as a urinary biomarker. Arch Environ Contam Toxicol; 38 398-403.

Lavy TL, Mattice JD, Massey JH, Skulman BW. (1993) Measurements of year-long exposure to tree nursery workers using multiple pesticides. Arch Environ Contam Toxicol; 24 123-144.

Lisi P, Caraffini S, Assalve D. (1987) Irritation and Sensitization Potential of Pesticides. Contact Dermatitis; 17 212-218.

Maddy KT, Krieger RI, Oconnell L, Bisbiglia M, Margetich S. (1989) Use of Biological Monitoring Data from Pesticide Users in Making Pesticide Regulatory Decisions in California - Study of Captan Exposure of Strawberry Pickers. Acs Symposium Series; $382338-353$.

Mcjilton CE, Berckman GE, Deer HM. (1983) Captan Exposure in Apple Orchards. Am Ind Hyg Assoc J; 44 209-210. 
National Institute for Occupational Safety and Health. (2007). DHHS Publication No 2005-149, -454: 2007. NIOSH pocket guide to chemical hazards. Cincinnati, Ohio. National Institute for Occupational Safety and Health.

Oudbier AJ, Bloomer AW, Price HA, Welch RL. (1974) Respiratory Route of Pesticide Exposure As A Potential Health Hazard. Bull Environ Contam Toxicol; 12 1-9.

Phalen RN, Que Hee SS. (2003) Permeation of captan through disposable nitrile glove. J Hazard Mater; 100 95-107.

Ritcey G, Frank R, McEwen FL, Braun HE. (1987) Captan residues on strawberries and estimates of exposure to pickers. Bull Environ Contam Toxicol; 38 840-846.

Ross JH, Driver JH, Cochran RC, Thongsinthusak T, Krieger RI. (2001) Could pesticide toxicology studies be more relevant to occupational risk assessment? Ann Occup Hyg; 45 S5-S17.

Spencer JR, Sanborn JR, Hernandez BZ, Krieger RI, Margetich SS, Schneider FA. (1995) Long vs. short monitoring intervals for peach harvesters exposed to foliar azinphosmethyl residues. Toxicol Lett; 78 17-24.

Stamper JH, Nigg HN, Queen RM. (1987) Dislodgeable Captan Residues at Florida Strawberry Farms. Chemosphere; 16 1257-1271.

Stevens ER, Davis JE. (1981) Potential Exposure of Workers During Seed Potato Treatment with Captan. Bull Environ Contam Toxicol; 26 681-688. 
Stewart PA, Prince JK, Colt JS, Ward MH. (2001) A method for assessing occupational pesticide exposures of farmworkers. Am J Ind Med; 40 561-570.

Thongsinthusak T, Ross JH, Saiz SG, Krieger RI. (1999) Estimation of dermal absorption using the exponential saturation model. Regul Toxicol Pharmacol; 29 37-43.

Tielemans E, Louwerse E, de Cock J, Brouwer D, Zielhuis G, Heederik D. (1999) Exposure to fungicides in fruit growing: Re entry time as a predictor for dermal exposure. Am Ind Hyg Assoc J; 60 789-793.

Tomlin C. (1997) The Pesticide Manual - World Compendium, $10^{\text {th }}$ edition. British Crop Protection Council: Thornton Heath. ISBN 9781901396263.

Trochimowicz HJ, Kennedy GL, Krivanek ND. (1991) Heterocyclic and miscelaneous nitrogen compounds. In Clayton GD, Clayton FE editors. Patty's Industrial Hygiene and Toxicology, $4^{\text {th }}$ edition, Vol. 2, part E. Wiley: New York. p. 3285-3521. ISBN 978047 1012825.

United States Environmental Protection Agency. (1975). EPA/540-1-75-012: 1975. Initial scientific and mini-economic review of captan. Washington, D.C.. United States Environmental Protection Agency, Office of Pesticide Programs, Criteria and Evaluation Division.

United States Environmental Protection Agency. (1999). EPA 738-R-99-011: 1999. Registration Eligibility Decision (RED) - Folpet. Washington, D.C.. US Environmental Protection Agency. 
United States Environmental Protection Agency. (2004). 69 Fed. Reg. 68357-68360: 2004. Amendment to the 1999 captan Registration Eligibility Decision (RED). Captan: cancer reclassification. Washington, D.C.. US Environmental Protection Agency.

van Welie RT, van DP, Lamme EK, Jager P, van Baar BL, Vermeulen NP. (1991) Determination of tetrahydrophtalimide and 2-thiothiazolidine-4-carboxylic acid, urinary metabolites of the fungicide captan, in rats and humans. Int Arch Occup Environ Health; $63181-186$

Verberk MM, Brouwer DH, Brouwer EJ, Bruyzeel DP, Emmen HH, van Hemmen JJ, Hooisma J, Jonkman EJ, Ruijten MW, Salle HJ. (1990) Health effects of pesticides in the flower-bulb culture in Holland. Med Lav; 81 530-541.

Viau C, Lafontaine M, Payan JP. (2004) Creatinine normalization in biological monitoring revisited: the case of 1-hydroxypyrene. Int Arch Occup Environ Health; 77 177-185.

Wester RC, Maibach HI. (1983) Cutaneous pharmacokinetics: 10 steps to percutaneous absorption. Drug Metab Rev; 14 169-205.

Winterlin WL, Kilgore WW, Mourer CR, Hall G, Hodapp D. (1986) Worker Reentry Into Captan-Treated Grape Fields in California. Arch Environ Contam Toxicol; 15 301-311.

Winterlin WL, Kilgore WW, Mourer CR, Schoen SR. (1984) Worker Reentry Studies for Captan Applied to Strawberries in California. J Agric Food Chem; 32 664-672. 
Woollen BH. (1993) Biological monitoring for pesticide absorption. Ann Occup Hyg; 37 $525-540$.

Zweig G, Leffingwell JT, Popendorf W. (1985) The relationship between dermal pesticide exposure by fruit harvesters and dislodgeable foliar residues. J Environ Sci Health B; 20 27-59. 


\section{Table 1}

Characteristics of captan or folpet exposure for each worker following fungicide treatment and harvest activities.

\begin{tabular}{|c|c|c|c|c|c|}
\hline & \multicolumn{2}{|c|}{ Captan exposure $^{b}$} & \multicolumn{3}{|c|}{ Folpet exposure $^{\mathrm{c}}$} \\
\hline & Worker \#1 & Worker \#2 & Worker \#1 & Worker \#2 & Worker \#3 \\
\hline \multicolumn{6}{|l|}{ Application activities $^{\mathrm{a}}$} \\
\hline Active ingredient $\%$ & $80 \%$ captan & $80 \%$ captan & $50 \%$ folpet & $80 \%$ folpet & $25 \%$ folpet \\
\hline Amounts (kg) & $4 \mathrm{~kg}\left(\right.$ or $\left.1 \mathrm{~kg} \mathrm{ha}{ }^{-1}\right)$ & NR & $1 \mathrm{~kg} \mathrm{ha}^{-1}$ & $3.5 \mathrm{~kg}\left(\right.$ or $\left.1 \mathrm{~kg} \mathrm{ha}{ }^{-1}\right)$ & $1 \mathrm{~kg} \mathrm{ha}^{-1}$ \\
\hline Water volume & $4001 \mathrm{ha}^{-1}$ & $5001 \mathrm{ha}^{-1}$ & NR & $7001\left(2001 \mathrm{ha}^{-1}\right)$ & NR \\
\hline Treated area (hectares) & 2.5 & 5 & NR & 3.3 & NR \\
\hline Spraying date & $07-08 / 05 / 2009$ & 08/08/2009 & $25 / 06 / 2009$ & $07-08 / 05 / 2009$ & $16 / 05 / 2009$ \\
\hline Total spraying duration & $2 \mathrm{~h}$ & $8 \mathrm{~h}$ & $4 \mathrm{~h}$ & $6 \mathrm{~h}$ & $3 \mathrm{~h}$ \\
\hline \multirow[t]{3}{*}{ Spraying technique } & Airblast pulled by a & Airblast pulled by a & Airblast sprayer & Airblast sprayer & Airblast sprayer and a \\
\hline & tractor with an & tractor with a closed & & & back air-spray \\
\hline & opened cabin & cabin & & & \\
\hline Safety equipment worn & - Leather shoes & - Rubber boots & - Full-face helmet & - Complete forced & - Half-face helmet \\
\hline \multirow[t]{3}{*}{ during application } & - Waterproof gloves & - Cap & with filter & air helmet & with filter \\
\hline & & & - Coveralls & - Tissue coveralls & - Tissue hat \\
\hline & & & - Waterproof gloves & - Safety shoes & - Waterproof gloves \\
\hline Symptoms & No & No & Eye irritation & No & Eye irritation \\
\hline
\end{tabular}




\begin{tabular}{|c|c|c|c|c|c|}
\hline & \multicolumn{2}{|c|}{ Captan exposure $^{b}$} & \multicolumn{3}{|c|}{ Folpet exposure $^{\mathrm{c}}$} \\
\hline & Worker \#1 & Worker \#2 & Worker \#1 & Worker \#2 & Worker \#3 \\
\hline \multicolumn{6}{|l|}{ Harvest activities } \\
\hline Active ingredient $\%$ & $80 \%$ captan & $80 \%$ captan & $50 \%$ folpet & $80 \%$ folpet & $60 \%$ folpet \\
\hline Harvesting date & $15 / 06 / 2009$ & 17 to $20 / 06 / 2009$ & $25 / 06 / 2009$ & 27 to $30 / 05 / 2009$ & 22 to $26 / 06 / 2009$ \\
\hline Total harvesting & $5 \mathrm{~h}$ & $30 \mathrm{~h}$ & $6 \mathrm{~h}$ & $36 \mathrm{~h}$ & $45 \mathrm{~h}$ \\
\hline \multicolumn{6}{|l|}{ duration } \\
\hline Symptoms & No & No & No & No & Eye irritation \\
\hline
\end{tabular}

$\mathrm{NR}=$ not reported.

${ }^{\text {a }}$ All workers performed mixing, loading, and material cleaning activities in addition to spaying.

${ }^{\mathrm{b}}$ Workers exposed to captan wore the same safety equipment during preparation and cleaning as described for application. No personal protective equipment was worn during harvesting period. Hands were washed after spraying and harvesting, and clothes were removed at home at the end of the workday for both activities. For worker 1, preparation was conducted inside and gloves only were decontaminated with water post-spraying. Conversely, for worker 2, preparation was conducted outside and no decontamination of equipment was performed post-spraying.

${ }^{\mathrm{c}}$ Workers exposed to folpet wore the same safety equipment during preparation and cleaning as described for application (excluding helmet), except worker 1 who had no personal protective equipment during cleaning. Preparation was conducted outside for worker 1 and inside with a ventilation system for the two other workers. Mask or helmet, gloves (workers 1-3), tissue coveralls (worker 2) and hat (worker 3) were decontaminated with soap and water post-spraying. The three workers washed their hands after spraying and harvesting. Worker 1 removed his clothes at home at the end of the workday after spraying activities and at work after harvest activities, worker 2 at work at the end of the workday after spraying activities and at 
home after harvest activities, and worker 3 at home at the end of the workday for both activities. For harvesting, worker 2 wore gloves and pants, and worker 3 wore rubber gloves only. 
Table 2

Published mean concentrations of THPI in the urine of workers exposed to captan following different activities in various types of crops.

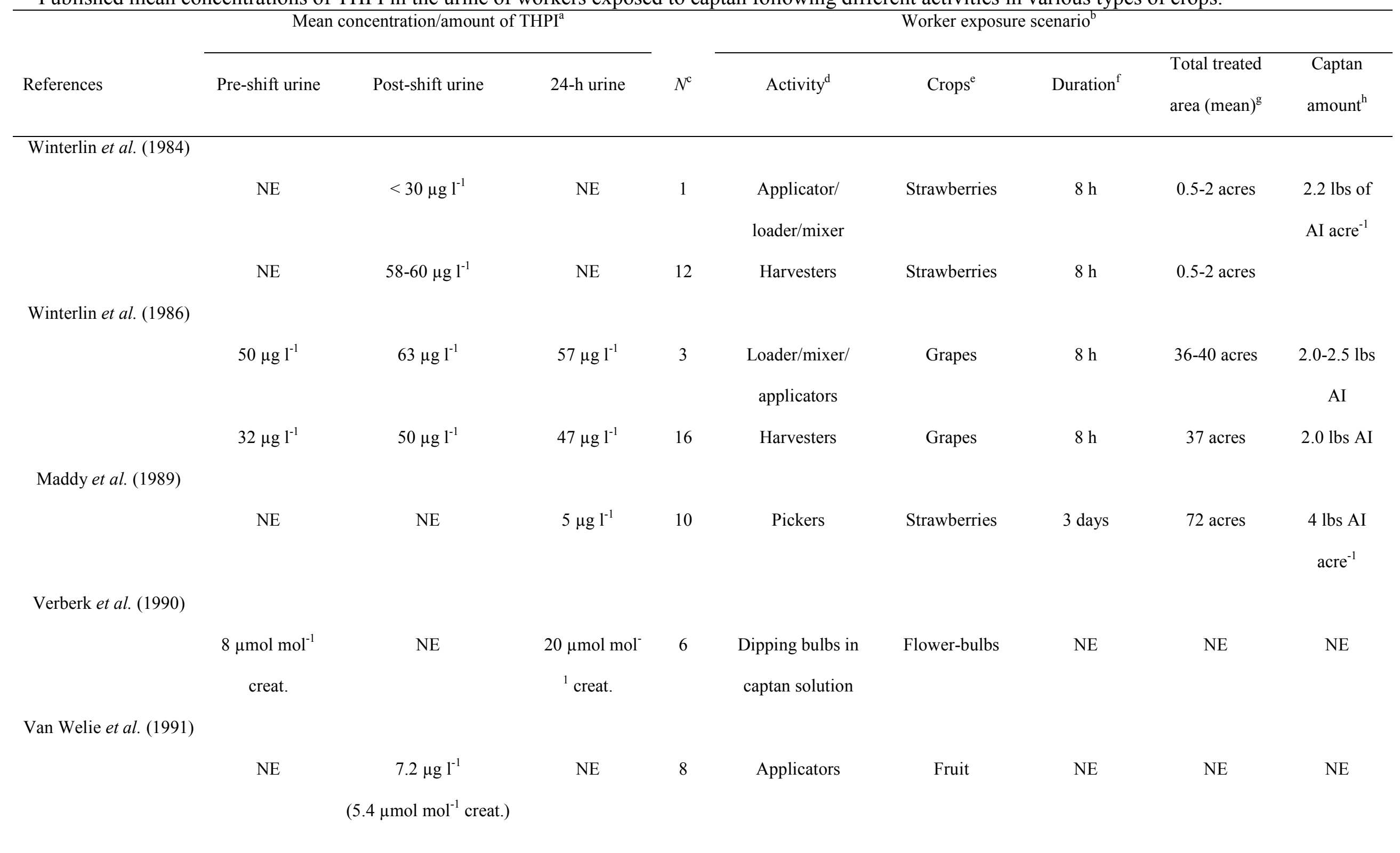




\begin{tabular}{|c|c|c|c|c|c|c|c|c|c|}
\hline \multirow[b]{2}{*}{ References } & \multicolumn{3}{|c|}{ Mean concentration/amount of THPI ${ }^{\mathrm{a}}$} & \multirow[b]{2}{*}{$N^{c}$} & \multicolumn{4}{|c|}{ Worker exposure scenario $^{b}$} & \multirow[b]{2}{*}{$\begin{array}{l}\text { Captan } \\
\text { amount }^{\mathrm{h}}\end{array}$} \\
\hline & Pre-shift urine & Post-shift urine & 24-h urine & & Activity $^{\mathrm{d}}$ & Crops $^{\mathrm{e}}$ & Duration $^{\mathrm{f}}$ & $\begin{array}{l}\text { Total treated } \\
\text { area (mean })^{\mathrm{g}}\end{array}$ & \\
\hline \multicolumn{10}{|c|}{ Lavy et al. (1993) } \\
\hline & & No THPI founded & & 73 & Applicators, & Conifer seedling & 12 consecutive & $\mathrm{NE}$ & 1.4 or 54.4 \\
\hline & & & & & weeders, scouts or & & weeks & & $\mathrm{kg}$ \\
\hline & & & & & packers & & & & \\
\hline \multicolumn{10}{|c|}{ De Cock et al. (1995) } \\
\hline & $\mathrm{NE}$ & $\mathrm{NE}$ & $11.5 \mu \mathrm{g}$ & 14 & Applicators & Fruit & $93 \mathrm{~min}$ & 14.8 acres & $10.4 \mathrm{~kg}$ \\
\hline \multicolumn{10}{|c|}{ Krieger and Dinoff } \\
\hline \multicolumn{10}{|c|}{$(2000)$} \\
\hline & No & $\mathrm{NE}$ & $2.0-5.3 \mu \mathrm{g}$ & 41 & Harvesters & Strawberries & 3 days & $102-162$ acres & $3.75 \mathrm{lbs}$ \\
\hline & background & & day $^{-1}$ & & & & & & $\operatorname{acre}^{-1}$ \\
\hline \multicolumn{10}{|c|}{ Hines et al. (2008) } \\
\hline & NE & $4.05 \mu \mathrm{g} / \mathrm{L}$ & $3.55 \mu \mathrm{g} / \mathrm{L}$ & 14 & Applicators & Strawberries & $211 \mathrm{~min}$ & 5.3 acres & $7.9 \mathrm{~kg}$ \\
\hline \multicolumn{10}{|c|}{ Our study } \\
\hline & $0.26 \mu g 1^{-1 i}$ & $2.70 \mu \mathrm{g} 1^{-1 \mathrm{i}}$ & $2.95 \mu \mathrm{g} 1^{-1 \mathrm{i}}$ & 2 & Loader/mixer/ & Apple trees & $2 \mathrm{~h}$ to $8 \mathrm{~h}$ & 2.5 to 5 acres & $1 \mathrm{~kg} \mathrm{AI}$ \\
\hline & $\left(1.69 \mathrm{nmol} \mathrm{l}^{-1}\right)$ & $\left(17.8 \mathrm{nmol} \mathrm{l}^{-1}\right)$ & $\left(19.5 \mathrm{nmol} \mathrm{l}^{-1}\right)$ & & applicators & & & & $\operatorname{acre}^{-1}$ \\
\hline & $0.14 \mu \mathrm{g}^{-1 \mathrm{i}}$ & $0.89 \mu \mathrm{g}^{-1 \mathrm{i}}$ & $0.59 \mu \mathrm{g} 1^{-1 \mathrm{i}}$ & 2 & Pruning, thinning & Apple trees & $5 \mathrm{~h}$ to $30 \mathrm{~h}$ & 2.5 to 5 acres & $1 \mathrm{~kg} \mathrm{AI}$ \\
\hline & $\left(0.93 \mathrm{nmol} \mathrm{l}^{-1}\right)$ & $\left(5.88 \mathrm{nmol} \mathrm{l}^{-1}\right)$ & $\left(3.90 \mathrm{nmol} \mathrm{l}^{-1}\right)$ & & & & & & acre $^{-1}$ \\
\hline
\end{tabular}

$\mathrm{NE}=$ not estimated $\mathrm{AI}=$ active ingredient; $\mathrm{lbs}=$ pounds. 
${ }^{a}$ Mean concentration or amounts of THPI measured in urine of workers exposed to captan.

${ }^{\mathrm{b}}$ Information concerning worker exposure to captan: activities during exposure, type of studied crops, duration of exposure, mean total treated area and amounts of captan applied on fields during the studied period.

${ }^{\mathrm{c}}$ Number of workers participating in the study.

${ }^{\mathrm{d}}$ Activities performed by workers during the studied period of exposure to captan.

${ }^{\mathrm{e}}$ Studied crop fields.

${ }^{\mathrm{f}}$ Duration of worker exposure to captan during the study period.

${ }^{\mathrm{g}}$ Mean total area (expressed in acres) treated with captan.

${ }^{\mathrm{h}}$. Mean amounts of captan (as active ingredient) sprayed during the study period.

${ }^{\mathrm{i}}$ Mean THPI levels calculated from data of both workers. 


\section{FIGURE CAPTIONS}

\section{Figure 1}

Time courses of THPI urinary excretion rate (expressed as nmol/h/ $\mathrm{kg}$ of body weight) over a 168-h period in two workers exposed to captan following spraying activities (A) and harvest activities in a captan-treated area (B). Arrows represent treatment period or harvesting period (for the two workers).

\section{Figure 2}

Time courses of PI (A and $\mathrm{B})$ and $\mathrm{PA}_{\mathrm{eq}}(\mathrm{C}$ and $\mathrm{D})$ urinary excretion rate (expressed as $\mathrm{nmol} / \mathrm{h} / \mathrm{kg}$ of body weight) over a 168 -h period in three workers exposed to folpet following spraying activities (A and $\mathrm{C}$ ) and harvest activities after a delay-of-rentry (B and D). Arrows represent treatment period or harvesting period (for the three workers).

\section{Figure 3}

Time courses of THPI excretion rates (expressed as $\mathrm{nmol} / \mathrm{h} / \mathrm{kg}$ of body weight) nonadjusted (open symbols) and adjusted by creatinine (closed symbols) in spot urines (A) or 8-h (C), 12-h (D) and 24-h (B) collections in a worker exposed to captan during spraying activities. The dermal maximum lines represent maximum values measured in the urine of volunteers exposed to $10 \mathrm{mg} / \mathrm{kg}$ of captan by the dermal route (Berthet et al., 2011b). 


\section{Figure 4}

Time courses of PI excretion rates (expressed as $\mathrm{nmol} / \mathrm{h} / \mathrm{kg}$ of body weight) non-adjusted (open symbols) and adjusted by creatinine (closed symbols) in spot urines (A) or 8-h (C), 12-h (D) and 24-h (B) collections in a worker exposed to folpet during spraying activities. The dermal and oral maximum lines represent maximum values measured in the urine of volunteers exposed to $10 \mathrm{mg} / \mathrm{kg}$ of folpet by the dermal route or $1 \mathrm{mg} / \mathrm{kg}$ by the oral route (Berthet et al., 2011a, b).

\section{Figure 5}

Dermal model simulations (solid line) compared with experimental data on the time courses of THPI and PI in the urine of a worker exposed to captan or folpet over a work week following spraying and harvest activity periods. Solid circles and gray outlines show experimental rate values in 24-h collections, black bars represent the corresponding simulated absorbed dose scenario (at given time points) with values on the right axis, and lines characterize model simulations for a dermal route exposure (solid lines), an oral route exposure (dashed lines) and an inhalation exposure (dotted-dashed lines). 


\section{FIGURES}

Figure 1

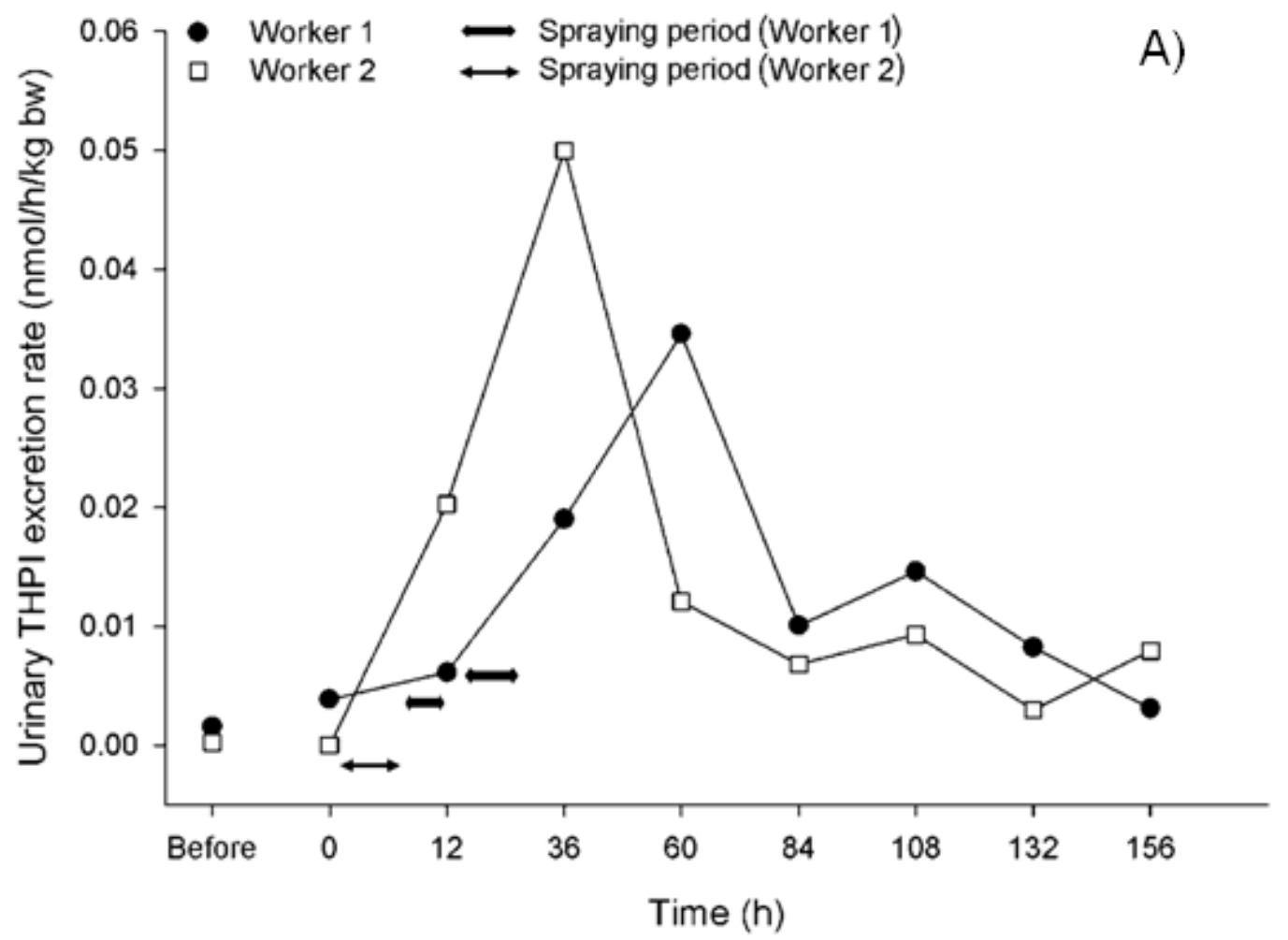

B)

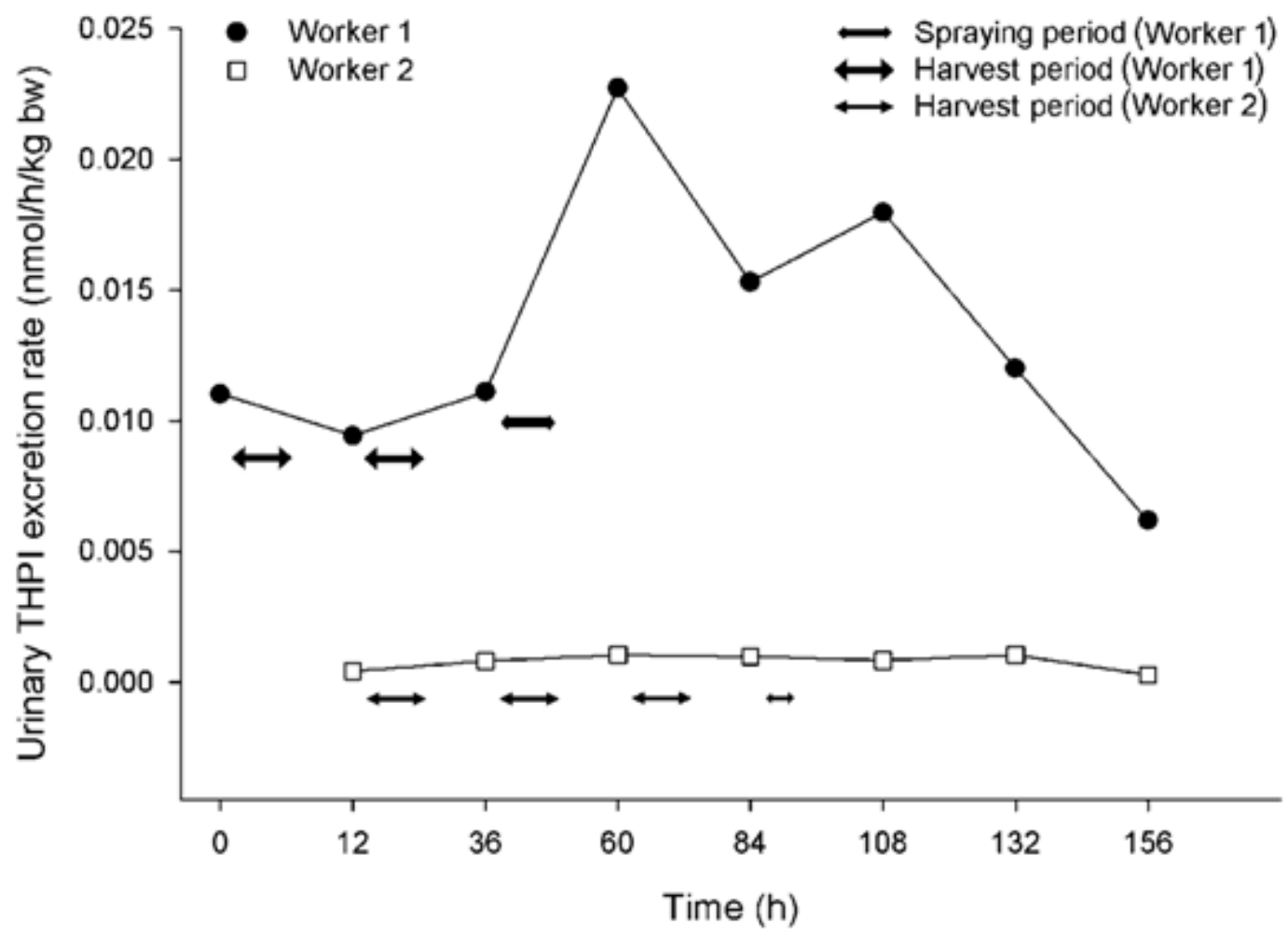


Figure 2
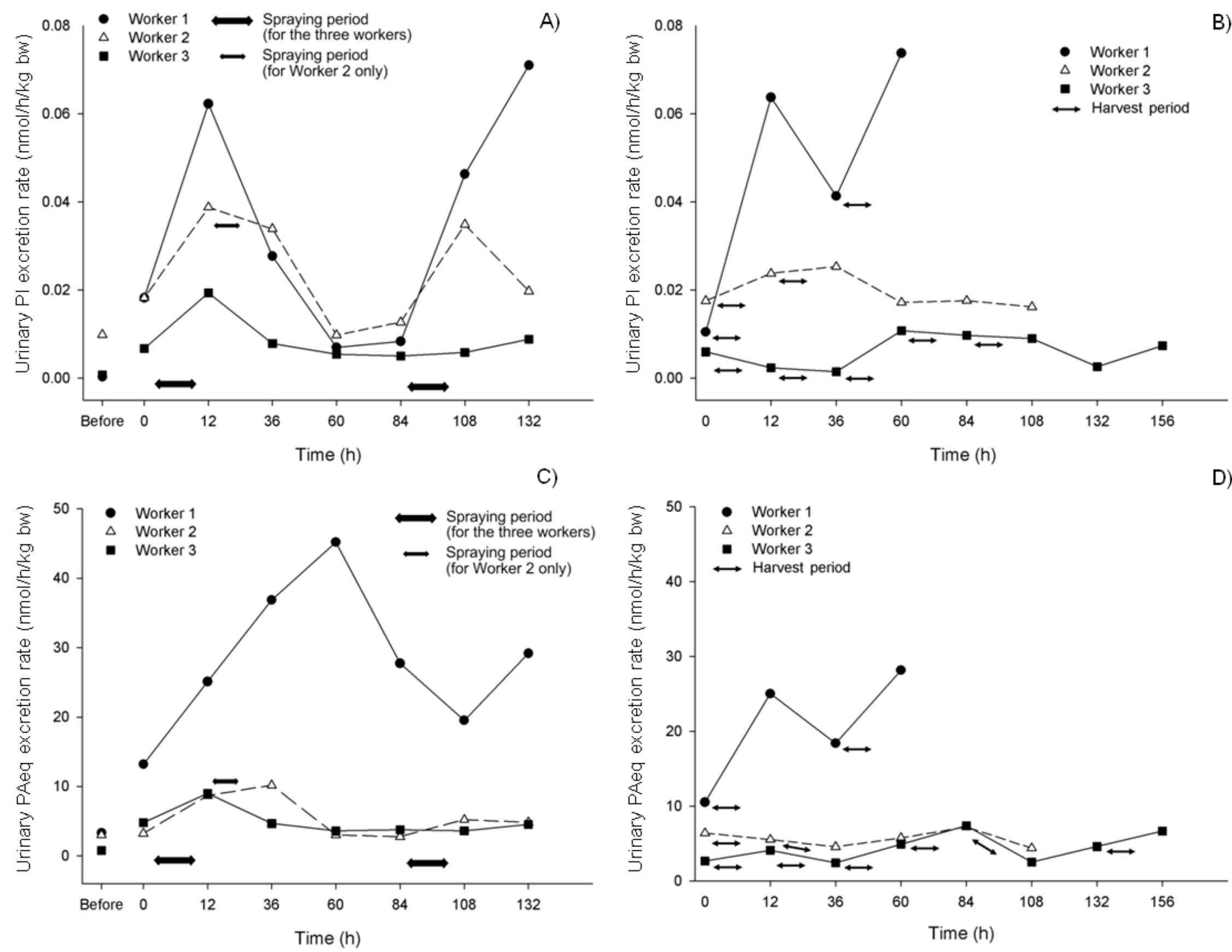
Figure 3

A)
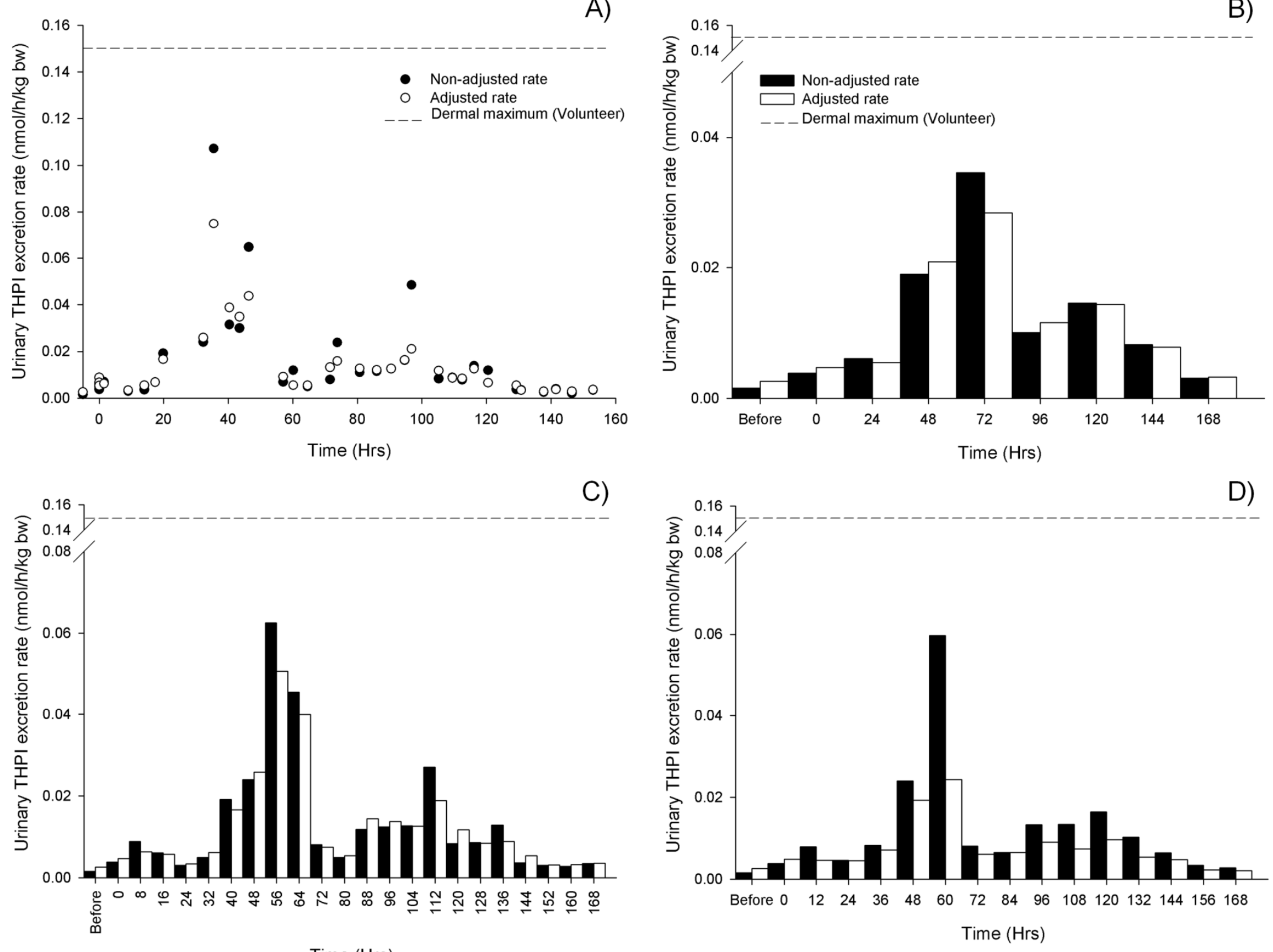
Figure 4

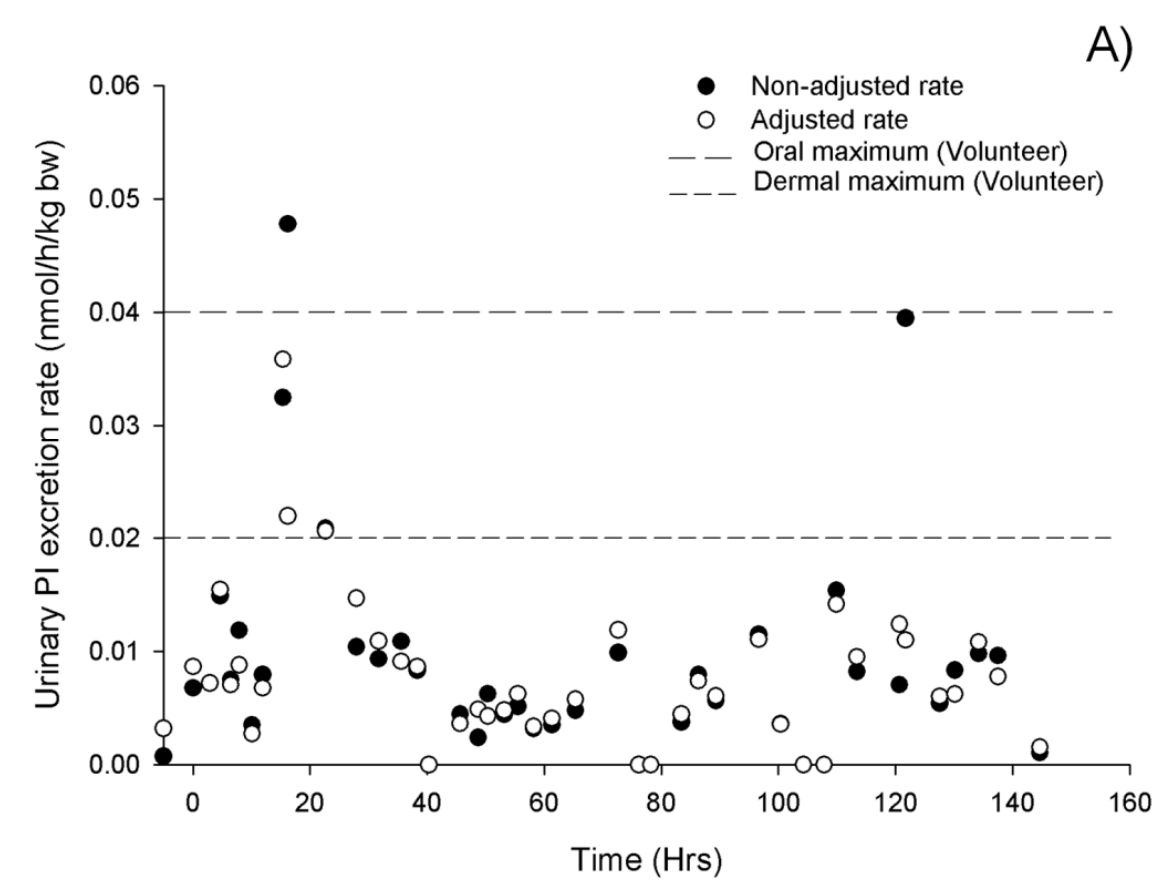

60

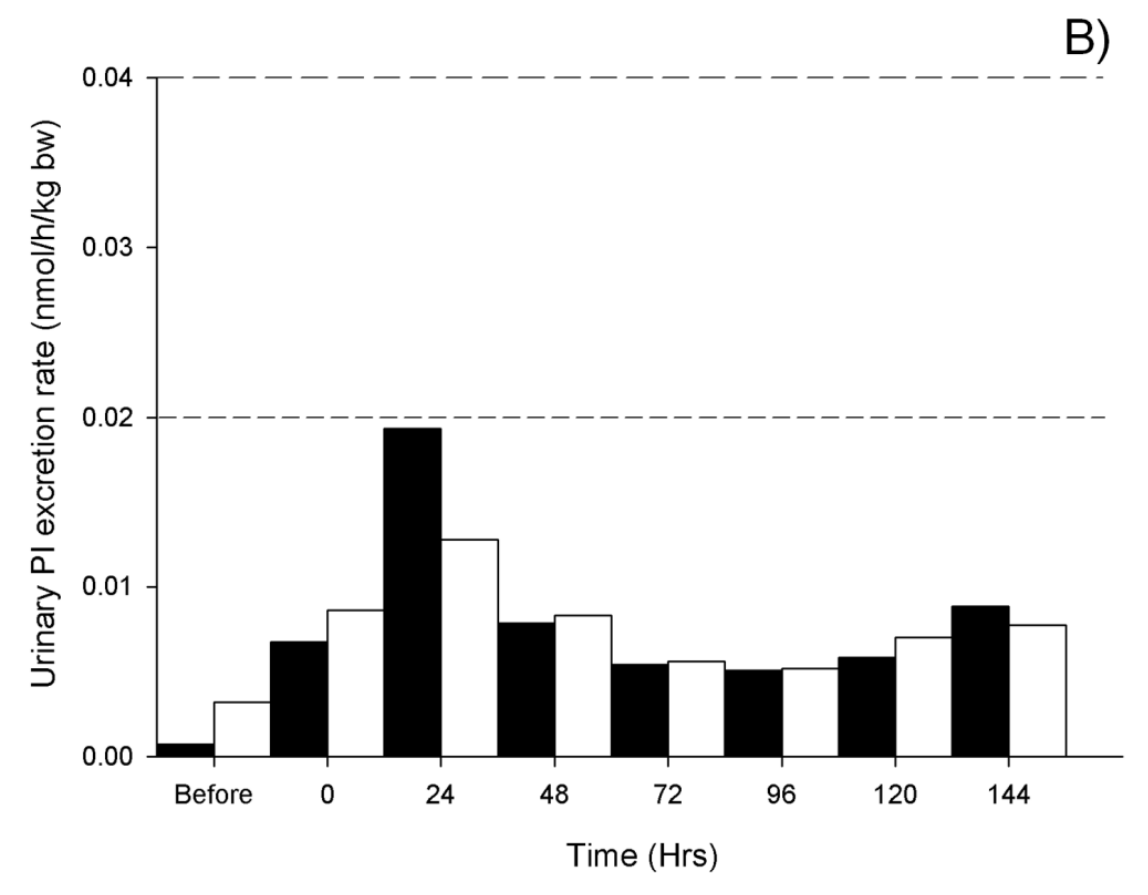

C)
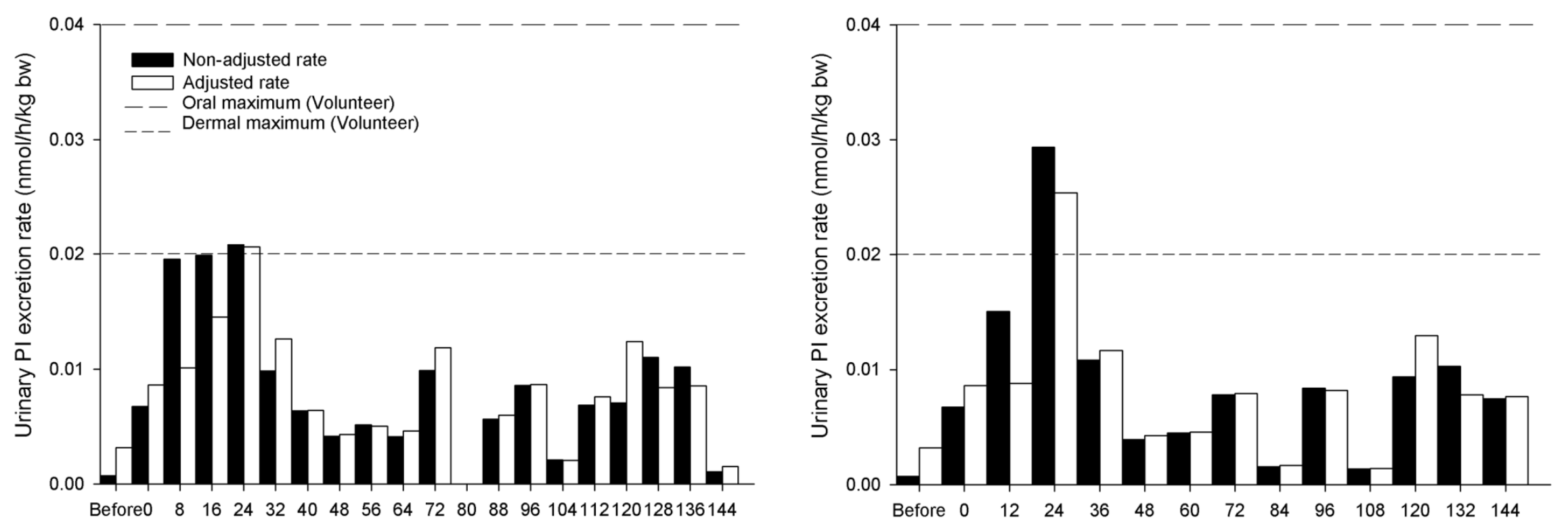
Figure 5

\section{SPRAYING ACTIVITIES}
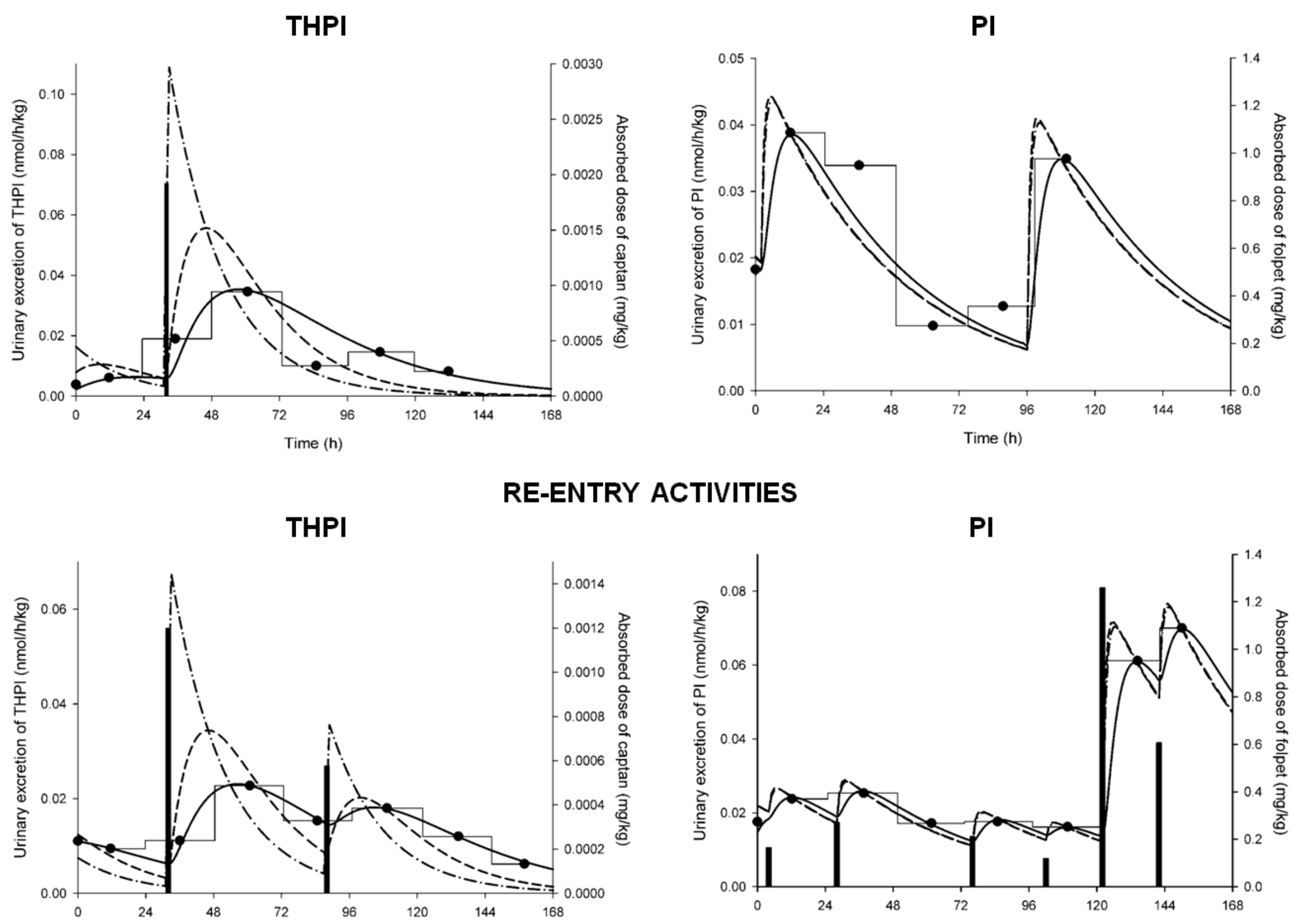